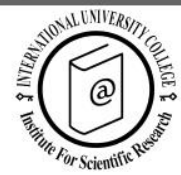

\title{
Economic strategy of the hospitality industry development in the Russian Federation: methodology and practice
}

\author{
Sergey Skobkin ${ }^{1}$
}

RECEIVED: 15/01/2014

\begin{abstract}
${ }^{1}$ Department of Hotel and Tourist Business, Plekhanov Russian University of Economics, Stremyanny pereulok dom 36, Moscow 117997, Russian Federation, Phone: +7 916634 0506, E-mail: skobkin.s@yandex.ru
\end{abstract}

Supervisors: Prof. Mikhail Yurievich Laiko, Department of Hotel and Tourist Business, Plekhanov Russian University of Economics

Institution awarding the Ph. D. Degree: The Plekhanov Russian University of Economics

Date of defence: $30^{\text {th }}$ October 2013

(c) 2014 International University College. All rights reserved

Citation: Skobkin, S. (2014). Economic strategy of the hospitality industry development in the Russian Federation: methodology and practice. Doctoral Dissertation Summary. European Journal of Tourism Research 8, pp. 166-169

\section{Goal and objectives of the dissertation}

The goal of the dissertation is to develop the methodology of economic strategy formation as well as the tool of its implementation in the business of hospitality industry enterprises.

The achievement of pre-determined goal indicates the necessity of approaching the following objectives:

1. Examine the concept and structure of the hospitality industry as the object of the service sector in the Russian Federation and abroad and to formulate proposals for its improvement. 2. Clarify the content of scientific concepts and criteria of strategic management in the hospitality industry based on economic strategy.

3. Justify the meaning of the growth of business value and economic profit for the strategic development of enterprises in the hospitality industry.
4. Identify the importance of the economic strategy as a tool for the formation of competitive advantages for enterprises in the hospitality industry.

5. Summarise and systematise the concepts of strategic development of the global hospitality industry.

6. Establish links between concepts and theoretical approaches to the development of the hospitality industry with the theory of strategic management.

7. Explore the modern trends of development of hotel, restaurant, transport, tourism enterprises in the global hospitality industry and they used strategies, and develop proposals for improving the efficiency of Russian enterprises in this sector of economic activity.

8. Develop a classification model of the system integrative stages of strategic development for enterprises in the hospitality industry with 
informed choice of instruments of economic strategy.

9. Suggest portfolios of strategies to achieve economic profit, gain competitive position and to increase value of assets of the enterprise.

10. Develop a model of the formation and implementation of economic strategies, applicable for any type of hospitality business.

11. Develop optimisation models of development and implementation of economic strategy in the activity of enterprises of the hospitality industry.

12. Propose a methodology to determine the effect from implementation of the economic strategy by enterprises in the hospitality industry.

\section{Methodology}

Mixed methods research is used in dissertation as well as the procedure for collecting and analyzing both quantitative and qualitative data to understand problem. The hospitality industry was divided in four major groups: hotels, restaurants, transport companies, mainly airlines and airports and tourist companies. Every element and their performance were researched.

Primary data were obtained through observations, semi-structured interviews with hotel and restaurant managers, as well as representatives of various tourist firms, organisations and associations, site visits and venues inspections. Author is grateful to administrations of Moscow hotels Radisson, Savoy, Cosmos, restaurant chains in Moscow MacDonald's, KFC International Holdings Inc., Inna Tours, Intourist, Russian Union of Tourist Industry, Russian Hotel Association and many others for opportunity to discuss and collect information for this research.

Secondary data were obtained from various publications of WTO-UN, World Travel and Tourism Council, Euromonitor, Federal State Spastics Service of Russian Federations, The Russia Federal Agency for Tourism as well as revues in relevant magazines, newspapers, articles in web sites.

The author's professional expertise in this area enables the collection of significant up-to-date information concerning the hospitality industry in Russian Federation.

\section{Results}

The most significant results of the doctoral dissertation received by the author are as follow:

Theory and Methodology:

The existing concepts, trends and opinions of strategic development in the hospitality industry were systematised and made it possible for author to propose a division of strategic management into following periods: 1) Formation of the hospitality industry (late XIX early $X X$ century), 2) The emergence of formal and informal conditions of business for enterprises in hospitality industry (1910 1945), 3) Integrative development of the hospitality industry through chains and global expansion (1946 - 1970), 4) Value Based Management approach in management of hospitality industry enterprises (1970 - 1990), 5) Competences and formation of unique technologies in hospitality industry (1990 present).

\section{New methodology in developing strategies in hospitality industry}

Based on analysis of international practice a model of cluster for hospitality services was developed. The proposed cluster allows concentrating in one limited area the whole range of interconnected enterprises and organisations which are engaged in the development, production, promotion and sale of hospitality services, as well as other sectors of economy, supporting the hospitality industry. Critical reflection of views of foreign and Russian scientists and experts on the development strategy of the global hospitality industry has allowed the author to establish differentiation and fragmentation of the strategies associated with a variety of different concepts of strategic development.

While analysing the process of strategy development the author revealed a relationship of economic strategy, business model and tactics.

Drivers to develop hospitality industry in Russian Federation were clarified and the 
technique to design business models was presented to determine how an enterprise in hospitality industry creates and provides value to customers, and then converts customer's revenues into profit. A structured model of economic strategy for integrative strategic development was offered and indicators identifying achievement level of following strategic goals were set: achieve economic profit, gain competitive positions and grow market value of assets in hospitality industry enterprise.

The author proposed the portfolio of strategies for each stage of strategic development of enterprises in hospitality industry on the basis of a structured model of economic strategy. Methods of optimisation of economic strategy were suggested. At the stage of development optimisation considers proposed portfolio strategies with the strategic resources of the company. At the stage of implementation optimisation must include portfolio strategies with the main economic indicators of activity of the enterprise.

\section{New concepts introduced by the author:}

The concept of integrative strategic effect from implementation of the economic strategy was formulated and the formula of calculation was introduced. It represents the difference between the market value of assets of the enterprise reached in the conditions of integrative strategic development and the carrying amount of assets of an enterprise formed for the same period. The author's technique of definition of integrative strategic effect after implementation of the economic strategy was introduced. It contains a synthesis of the economic profit model and the discounted cash flow.

\section{Theoretical conclusions}

The research presents theoretical and practical conclusions which made it possible the author to generalise and formulate the existence of systemic integrative stages of strategic development of enterprises through direct or indirect registration of events, characteristic, objects and processes of hospitality industry. The complex of the revealed integrative characteristics of these stages was combined in the concept of strategic development, based on the formation of economic strategy of which review and description the dissertation is devoted. Significance of dissertation for science is in the development of comprehensive approach to methodologies to improve the efficiency of the strategic management of the enterprises of the industry of hospitality based on integrative stages of economic strategy.

\section{Practical application of the dissertation}

The practical significance of the dissertation research is that the proposed findings and recommendations can be used in the practice of hospitality industry in order to improve strategic management, competitiveness, rapid adaptation to the intense competition in the global and Russian markets. Some of the findings and suggestions can be used by the expert groups in developing long-term strategies for enterprises and institutions of the hospitality industry at the regional and municipal level.

\section{Content of the dissertation \\ Abstract of introduction}

In introduction the actuality of the chosen theme of the scientific researches is formulated. The author describes the objective, tasks, object, subject and methodological basis of the research, the degree of knowledge of the main problems in this field of science.

\section{Abstract of chapter one}

In the first chapter the theoretical foundations of strategic management in the hospitality industry are considered. The notions of the hospitality industry as the object of study in the field of services as well as the model of strategic management of hospitality industry are developed by the author. Besides advocating in favour of Value Based Management, the nature of economic profit and its importance for the strategic development of the company, author clarified the concept of economic strategy as a tool for formation of competitiveness, identifying drivers to achieve the business objectives.

\section{Abstract of chapter two}

In the second chapter, a study of methodologies and concepts aimed at improving the efficiency of the strategic 
development of the hospitality industry were conducted. The author's position of systematisation and periodisation of stages of strategic development of hospitality industry were presented. The analysis of the structural theory of the three stages of the development of demand in the hospitality services made it possible to establish relationship with the concept of competitive strategies. The concept of sustainable tourism development and a model of cluster creation of hospitality services in the Russian Federation were investigated.

The chapter summarised the approaches to the concept of throughput tourism capacity for the hospitality industry and established its relationship with the resource theory. The peculiarities of application of the quantitative theory of strategic changes in the hotel business are considered and its relationship with competence approach in strategic management is discovered.

\section{Abstract of chapter three}

In the third chapter the research of the modern state of the global hospitality industry is conducted. Estimation of the world market of hospitality services, including in the Russian Federation are presented and issues that hindered its development are identified. The practice of application of the strategies of the growth of the leaders in the global hospitality industry is studied.

\section{Abstract of chapter four}

The fourth chapter deals with the concept of strategic development on the basis of integrative stages. The author suggests portfolio strategies and methods of their organisation, which include the following: achieve economic profit; strengthening competitive position and increase the market value of assets of hospitality industry enterprise.

\section{Abstract of chapter five}

In the fifth chapter the methodology for implementation of the economic strategy in the activity of enterprises of the hospitality industry is proposed. Methods include optimisation of the economic strategy at the stage of its development and at the stage of its implementation.

In conclusion the results of the dissertation research are summarised, the main conclusions are formulated and practical recommendations on introduction of developed techniques are given. 